Images in...

\title{
Muscle weakness and a sustained handgrip (a video demonstration)
}

\author{
Arjun Maitra, ${ }^{1}$ Madhav Bansal, ${ }^{2}$ Anil Kapoor, ${ }^{3}$ Rakesh Biswas ${ }^{3}$
}

${ }^{1}$ Department of Physiology, People's College of Medical Sciences, Bhopal, India;

2Department of Community Medicine, People's College of Medical Sciences, Bhopal, India;

${ }^{3}$ Department of Medicine, People's College of Medical Sciences, Bhopal, India

Correspondence to Rakesh Biswas, rakesh7biswas@gmail.com

\section{DESCRIPTION}

A 52-year-old male farmer presented to us with a history of gradual weakness of his lower limb with initial difficulty in getting up from sitting that progressed to difficulty in combing his hair.

On examination he was found to have frontal baldness, with mild temporal wasting and MRC grade III/V power in his shoulders and hips with inability to raise the hands against resistance and inability to get up from squatting.

His younger brother came to the hospital to pay him a visit and we noticed he had similar features although with more prominent temporal wasting and frontal baldness. There are four brothers; the elder two did not have any hair loss or wasting or weakness.

The diagnosis was further established clinically on testing their handgrip (videos $1 \mathrm{~A}$ and $\mathrm{B}$ ).

Video 1 (A, B) Shaking hands - note patient's difficulty in release 10.1136/bcr.04.2009.1819v1a 10.1136/bcr.04.2009.1819v1b

This was a classical presentation and the diagnosis was made clinically. The key clinical diagnostic feature (as also shown in the videos) is a delayed relaxation of muscle after sudden forceful contraction. ${ }^{1}$ The differential diagnosis of myotonic dystrophy includes other causes of myotonia: paramyotonia, congenital myotonia, mild tetanus and the rare stiff man syndrome. At later stages, the myotonic dystrophy may resemble limb-girdle atrophy, polymyositis or dermatomyositis. ${ }^{2}$ DNA testing is definitive for the diagnosis and before it became available the electromyography was used and often showed a typical myotonic discharge with a waxing and waning quality giving rise to the descriptive term, the 'divebomber' sound. In myotonia, abnormalities in specific sarcolemmal ion conductances can lead to a reduced electrical threshold for firing action potentials and in conduction of repetitive impulses that result in sustained muscle fibre contraction. $^{3}$

\section{Competing interests None.}

Patient consent Obtained.

\section{REFERENCES}

1. Streib EW. Differential diagnosis of myotonic syndromes. Muscle Nerve 1987; 10:603-15.

2. Hogans B, Novella S. Myotonic Dystrophy. http://www.med.yale.edu/neurol/ programs/neuromuscular/myontonic_dystrophy.html (accessed 10 Aug 2009).

3. Rüdel R, Lehmann-Horn F. Membrane changes in cells from myotonia patients. Physiol Rev 1985;65:310-56.

This pdf has been created automatically from the final edited text and images.

Copyright 2011 BMJ Publishing Group. All rights reserved. For permission to reuse any of this content visit http://group.bmj.com/group/rights-licensing/permissions.

BMJ Case Report Fellows may re-use this article for personal use and teaching without any further permission.

Please cite this article as follows (you will need to access the article online to obtain the date of publication).

Maitra A, Bansal M, Kapoor A, Biswas R. Muscle weakness and a sustained handgrip (a video demonstration). BMJ Case Reports 2011; 10.1136/bcr.04.2009.1819, date of publication

Become a Fellow of BMJ Case Reports today and you can

- Submit as many cases as you like

- Enjoy fast sympathetic peer review and rapid publication of accepted articles

- Access all the published articles

- Re-use any of the published material for personal use and teaching without further permission

For information on Institutional Fellowships contact consortiasales@bmjgroup.com

Visit casereports.bmj.com for more articles like this and to become a Fellow 